\title{
Cultivar, Planting Density, and Plant Growth Regulator Effects on Growth and Fruiting of Tissue- cultured Apple Trees
}

\author{
Richard H. Zimmerman and George L. Steffens \\ U.S. Department of Agriculture, Agricultural Research Service, Fruit Laboratory, Beltsville, MD 20705-2350
}

Additional index words. burrknots, cultural practices, daminoride. ethephon, Malus domestica, micropropagation, paclobutrazol, rootstocks, uniconazole

\begin{abstract}
Tissue-culture (TC)-propagated 'Gala' and Triple Red 'Delicious' apple trees grown at three planting densities were not treated (CON) or treated with plant growth regulators (PGRs) starting the third or fourth season to control tree size and maximize fruiting. 'Gala' and 'Delicious' trees budded on M.7a rootstock (BUD) were also included as controls. 'Gala' trees were larger than 'Delicious' after the first three growing seasons but 'Delicious' were larger than 'Gala' at the end of 9 years. BUD trees were larger than CON trees the first few seasons hut final trunk cross-sectional area (TCSA) of CON trees averaged $43 \%$ greater than BUD trees. Paclobutrazol and uniconazole treatments more readily controlled the growth of 'Gala' than 'Delicious' and uniconazole was more effective than paclobutrazol in controlling tree size. Daminozide + ethephon sprays (D+E-S) did not influence tree size. Tree size of both cultivars was inversely related to planting density and both triazole PGRs were more effective in controlling tree size as planting density increased. The trees had fewer flowers as planting density increased and BUD trees generally had more Bowers than CON. Triazole PGRs had little effect on the flowering pattern of 'Gala' trees but tended to stimulate flowering of young 'Delicious' TC trees, although the increases were not sustained. The D+E-S treatment increased flowering of 'Gala' trees the last 3 years of the experiment and consistently increased flowering of 'Delicious' TC trees. Fruit yields were higher for young 'Gala' compared to 'Delicious' trees and the final cumulative yield per tree for 'Gala' was also greater. Yield per tree decreased as tree density increased and was the same for BUD and CON trees. D+E-S increased cumulative per tree yield of 'Delicious' but not of 'Gala'. Cumulative yields per tree for triazole-treated TC trees were the same as, or significantly lower than, CON trees. Increasing tree density did not increase yield/ha. Yield efficiency of ' $G$ ala' trees was increased by three, and of 'Delicious' trees by one, of the triazole treatments, because they reduced TCSA proportionally more than they reduced per tree yield. There was less bienniality with 'Gala' than 'Delicious' and no difference between BUD and CON trees. Bienniality indices were higher for paclobutrazol-treated 'Gala' trees compared with CON 'Gala' but only uniconazole applied as a trunk paint increased the bienniality index of 'Delicious' trees. Chemical names used: succinic acid-2,2-dimethyl hydrazide (daminozide), (2-chloroethyl) phosphonic acid (ethephon), (2RS,3RS)-1-(4-chlorophenyl)4,4-dimethyl-2-(1,2,4-triazol-1-yl)pentan-3-01 (paclobutrazol), (E)-(l-chlorophenyl)-4,4-dimethyl-2-(I,2,4-triazol-l-yl)-
\end{abstract} 1-penten-3-ol (uniconazole).

Development of micropropagation methods to produce ownrooted apple trees was initiated originally to obtain trees that might replace conventional trees budded on vigorous to moderately vigorous rootstocks. The potential of such tissue-cultured (TC) trees would be increased if PGRs could control tree size similar to currently used rootstocks. Several trials have shown that TC trees were as vigorous as those on seedling or MM.111 rootstocks (Larsen and Higgins, 1993; Quamme and Brownlee, 1993; Rosati and Gaggioli, 1987, 1989; Webster et al., 1985; Zimmerman and Miller, 1991). Yields of the TC trees can be as high as, or higher than, trees of the same cultivar budded on productive rootstocks such as MM. 106, but the greater vigor of the TC trees results in lower yield efficiencies when these are calculated on the basis of trunk cross-sectional area (TCSA) (Larsen and Higgins, 1993; Rosati and Gaggioli, 1987, 1989; Zimmerman and Miller, 1991). Thus, control of the size of TC trees is desirable to increase the possibilities for use. The triazole plant growth retardants pa-

Received for publication 4 Apr. 1994. Accepted for publication 10 Aug. 1994. Paclobutrazol was provided by ICI Americas. uniconazole by Chevron Chemical Co., and daminozide and ethephon by Uniroyal. We thank Larry Douglass for advice and useful discussion $\backslash$ on cxperimental design and statistical analysis and Charles Mischke for preparing the figures. The cost of publishing this paper was defrayed in part by the payment of page charges. Under postal rcgulations, this paper therefore must he hereby marked advertisement solely to indicatc this fact. clobutrazol and uniconazole offered potential to reduce growth of TC trees (Davis et al., 1988: Miller, 1988: Davis and Curry, 1991). The objectives of this experiment were to evaluate several plant growth retardants using different application dosages and methods for their ability to control vegetative growth and to enhance early flowering and fruiting of micropropagated apple trees.

\section{Materials and Methods}

'Gala' and Triple Red 'Delicious' apple (Malus domestica Borkh.) trees were micropropagated (Zimmerman and Fordham, 1985), acclimatized in a greenhouse, and then transplanted to an orchard at Beltsville. Maryland in June, 1984 (Zimmerman and Steffens, 1989). Control trees of the same cultivars budded on M.7a rootstocks were planted in April 1984. The experiment was designed as a strip-split-plot with planting densities as main plots (high density $=1.8 \times 4.9 \mathrm{~m}, 1121$ trees $/$ ha; medium density $=2.7$ x $4.9 \mathrm{~m}, 747$ trees/ha; low density $=3.7 \times 4.9 \mathrm{~m}, 561 \mathrm{trees} / \mathrm{ha})$. The two cultivars and the eight plant growth regulator (PGR)-rootstock treatments were subplots. Each treatment was a four-tree plot replicated four times for a total of 768 experimental trees. Every ninth tree in each orchard row was a pollenizer.

Cultural practices. The planting site, a Beltsville fine sandy loam (Typic Fragiudult. fine-loamy, mixed, mesic). had been used previously as an orchard site for apples and peaches. TC trees were 
Table 1. Spray (S) concentrations $\left(\mathrm{mg} \cdot \mathrm{liter}^{-1}\right)$, trunk drench $(\mathrm{T})$. and trunk paint $(\mathrm{P})$ dosages $(\mathrm{mg} / \mathrm{tree})$ and number of applications of plant growth regulator treatment applied to tissue-cultured 'Gala' and Trinle Red 'Delicious' apple trees.

\begin{tabular}{|c|c|c|c|c|c|c|c|c|}
\hline \multirow[b]{2}{*}{ Treatment: } & \multirow{2}{*}{$\begin{array}{c}\text { Tree } \\
\text { density }\end{array}$} & \multirow[b]{2}{*}{ Cultivar" } & \multicolumn{6}{|c|}{ Ycar } \\
\hline & & & 1986 & 1987 & 1988 & 1989 & 1990 & 1991 \\
\hline \multirow{2}{*}{$\bar{D}+\mathrm{E}-\mathrm{S}$} & HML & $\overline{\mathrm{GT}}$ & $1000+$ & $1000+$ & $1000+$ & $1000+$ & $1000+$ & $1000+$ \\
\hline & & & $4\left(00-1 x^{2}\right.$ & $400-1 x$ & $400-1 x$ & $400-1 x$ & $400-1 x$ & $400-1 x$ \\
\hline \multirow[t]{6}{*}{$\mathrm{PAC}-\mathrm{S}$} & $\mathrm{H}$ & $\mathrm{G}$ & $250-3 x$ & $250-3 x$ & $375-3 x$ & --- & $250-3 x$ & $250-3 x$ \\
\hline & M & $\mathrm{G}$ & $-\cdots$ & $375-3 x$ & $375-4 x$ & --- & $250-3 x$ & $250-3 x$ \\
\hline & $\mathrm{L}$ & G & --- & $250-4 x$ & $375-4 x$ & --- & $250-3 x$ & $250-3 x$ \\
\hline & $\mathrm{H}$ & $\mathrm{T}$ & $250-3 x$ & $250-3 x$ & $375-3 x$ & $250-2 x$ & & $250-4 x$ \\
\hline & M & $\mathrm{T}$ & -- & $375-3 x$ & $375-4 x$ & $250-2 x$ & --- & $250-4 x$ \\
\hline & $\mathrm{L}$ & $\mathbf{T}$ & -- & $250-4 x$ & $375-4 x$ & $250-2 x$ & --- & $250-4 x$ \\
\hline \multirow[t]{6}{*}{ UNI-S } & $\mathrm{H}$ & G & $125-3 x$ & $125-3 x$ & $188-3 x$ & $125-3 x$ & $125-3 x$ & \\
\hline & M & $\mathrm{G}$ & --- & $188-3 x$ & $188-4 x$ & $125-3 x$ & $125-3 x$ & --- \\
\hline & $\mathrm{L}$ & $\mathrm{G}$ & --- & $125-4 x$ & $188-4 x$ & $125-3 x$ & $125-3 x$ & --- \\
\hline & $\mathrm{H}$ & $\mathrm{T}$ & $125-3 x$ & $125-3 x$ & $188-3 x$ & $125-3 x$ & -- & $125-3 x$ \\
\hline & M & $\mathrm{T}$ & --- & $188-3 x$ & $188-4 x$ & $125-3 x$ & --- & $125-3 x$ \\
\hline & $\mathrm{L}$ & $\mathrm{T}$ & --- & $125-4 x$ & $188-4 x$ & $125-3 x$ & --- & $125-3 x$ \\
\hline \multirow[t]{2}{*}{ PAC-T } & $\mathrm{H}$ & GT & $500-1 x$ & $250-1 x$ & --- & --- & $250-\mathrm{Ix}$ & --- \\
\hline & ML & GT & $-\cdots$ & $500-1 x$ & $250-1 x$ & $\cdots$ & $250-1 x$ & --- \\
\hline \multirow[t]{2}{*}{ UNI--T } & $\mathrm{H}$ & $\mathrm{GT}$ & $250-1 x$ & $125-1 x$ & $\cdots$ & $-\cdots$ & $125-1 x$ & -- \\
\hline & ML & GT & --- & $3.70-1 x$ & $125-1 x$ & -- & $125-1 x$ & --- \\
\hline \multirow[t]{2}{*}{ UNI-P } & $\mathrm{H}$ & GI & $500-1 x$ & -- & $\cdots$ & -- & $250-1 x$ & --- \\
\hline & ML. & GT & --- & $5(0)-1 x$ & & --- & $250-1 x$ & --- \\
\hline
\end{tabular}

${ }^{2} \mathrm{D}+\mathrm{E}=$ daminozide + ethephon spray; PAC-S = paclobutrazol spray; UNI-S = uniconazole spray: PAC-T = paclobutrazol trunk drench: UNI-T uniconazole trunk drench: UNI-P = uniconazole trunk paint.

${ }^{ } \mathrm{D}+\mathrm{E}-\mathrm{S}$ solution prepared using $85 \%$ daminozide and $240 \mathrm{~g}$ a.i. per liter ethephon; PAC-S and PAC-T solutions prepared from $240 \mathrm{~g}$ a.i. per liter emulsifiable concentrate; UNI-S and UNI-T solutions prepared using 50\% wettable powder; all solutions contained $0.1 \%$ polyoxyethylene (20) sorbitan monolaurate (Tween 20) surfactant. UNI-P contained uniconazole in an organic solvent-based formulation applied at $10 \mathrm{ml}$ per tree.

${ }^{x}$ High $(\mathrm{H})=1161$ trees/ha; medium $(\mathrm{M})=747$ trees/ha; low $(\mathrm{L})=561$ trees $/$ ha.

${ }^{\mathrm{w}} \mathrm{G}=$ Gala; $\mathrm{T}=$ Triple Red Delicious.

"Number of applications per year.

watered by hand several times in the first few weeks following planting and then were irrigated by a drip system. Trees were fertilized annually with urea(actual N $16 \mathrm{~kg} \cdot \mathrm{ha}^{-1}$ in 1985-1986,38 $\mathrm{kg} \cdot \mathrm{ha}^{-1}$ in $1987-88,31 \mathrm{~kg} \cdot \mathrm{ha}^{-1}$ in $\left.1990-1991\right)$ and $4.4 \mathrm{P}-8.3 \mathrm{~K} 336$ $\mathrm{kg} \cdot \mathrm{ha}^{-1}(1991)$ or $10 \mathrm{~N}-4.4 \mathrm{P}-8.3 \mathrm{~K} 336 \mathrm{~kg} \cdot \mathrm{ha}^{-1}(1989$, 1992).

An in-row weed-free strip $1.2 \mathrm{~m}$ wide was maintained using paraquat (1,1'-dimethyl-4.4'-bipyrdinium ion). After this strip was established, oryzalin (3,5-dinitro- $\mathrm{N}_{4}, \mathrm{~N}_{4}$-dipropylsulfanilamide) alone or in a tank mix with diuron [N'-(3.3-dichlorophenyl)-N,Ndimethylurea] or simazine (2-chloro-4,6-bis(cthylalnino)-s-tri 1 ine) was used for early season weed control.

Since fruit set was heavy, trees were hand-thinned in June 1989-91 to minimize limb breakage. In 1992. 'Gala' was thinned with a spray of 1-naphthaleneacetic acid (2.25 g/100 liters, 1870 liters $\cdot \mathrm{ha}^{-1}$ ) applied 11 May, 2 weeks after full bloom.

Treatment. The eight treatments consisted of two controls. 1) untreated trees budded on M.7a rootstock (BUD) and 3) untreated own-rooted TC-propagated trees $(\mathrm{CON})$. and six PGR treatments applied to TC trees (Table 1), 3) combined daminozide + ethephon sprays (D+E-S), 3) paclobutrazol sprays (PAC-S), 5) uniconazole sprays (UNI-S). 5) paclobutrazol trunk drench (PACT), 7) uniconazole trunk drench (UNI-T), and 8) a uniconazole formulation painted on the trunk (UNI-P) (Steffens and Zimmerman, 1990).

Sprays were applied to run-off. Aqueous trunkdrench solutions of $500 \mathrm{ml}$ were applied around the trunk of each tree at the soil line. The UNI-P treatment was brushed on the lower trunks of the trees starting $30 \mathrm{~cm}$ above the soil line.

Initial PGR application dosages and timings were selected to slow growth after the trees had partially filled their allotted spacc; therefore. trees planted at high density were treated one season earlier than trees planted at medium or low density. Also, we attempted to manage growth of the trees as they matured by modifying PGR treatment dosage and frequency of application (Table 1).

Data collection and analysis. Data collected annually from the center two trees of each four-tree plot included total number of flower clusters, the number and weight of fruit, the TCSA $30 \mathrm{~cm}$ above the ground, the final lengths of 10 lateral shoots and, through 1988, the height and spread. Crown volume (tree height $\times$ spread in the row $\mathrm{x}$ spread across the row) was calculated 1985-88. Yield efficiency was calculated as the cumulative weight $(\mathrm{kg})$ of fruit harvested per $\mathrm{cm}^{2}$ of 1992 TCSA.

A bienniality index for fruiting was calculated as described by Hoblyn et al. (1936) and modified by Elfving and Cline (1990). i.e., dividing the difference in yield for each consecutive pair of years by the their sum and multiplying by 100 . The index values were then averaged for the last 6 years of yield data.

Trees were evaluated for location and intensity of burrknot ("a many-branched. truncated root system arising independently on shoot tissues above the ground", Jones and Aldwinckle. 1990) formation in December 1992 before the trees were removed. For location. trees were scored for burrknots on the trunk below the lowest scaffold limbs, for burrknots on limbs or trunk from the lowest scaffold limb< up. or for burrknots in both places. Intensity was scored as $0=$ none. $1=$ light. $2=$ medium and $3=$ heavy.

Data were analyzed using the General Linear Model Procedure of SAS (SAS Institute, 1987). Treatment means were separated using Duncan's multiple range test and interaction means using the TDIFF option for the least-squares means (SAS Institute, 1987). 
Table 2. Main effects and interactions of cultivar, planting density, and treatment on final tree size (TCSA). cumulative yield, yield efficiency, and bienniality.

\begin{tabular}{|c|c|c|c|c|c|c|c|c|c|}
\hline \multirow[b]{2}{*}{ Factor } & \multirow{2}{*}{\multicolumn{2}{|c|}{$\begin{array}{l}\text { Final } \\
\text { TSCA } \\
\left(\mathrm{cm}^{2}\right)\end{array}$}} & \multicolumn{3}{|c|}{ Cumulative yield } & \multirow{2}{*}{\multicolumn{2}{|c|}{$\begin{array}{c}\text { Yield } \\
\text { efficiency } \\
\left(\mathrm{kg} \cdot \mathrm{cm}^{-2}\right)\end{array}$}} & \multirow{2}{*}{\multicolumn{2}{|c|}{$\begin{array}{c}\text { Mean } \\
\text { bienniality } \\
\text { index }\end{array}$}} \\
\hline & & & \multicolumn{2}{|c|}{$\begin{array}{c}\text { per tree } \\
(\mathrm{kg})\end{array}$} & \multirow[t]{2}{*}{$\begin{array}{c}\text { per ha } \\
\text { (t) }\end{array}$} & & & & \\
\hline \multicolumn{9}{|l|}{ Cultivar } & \\
\hline Gala & \multicolumn{2}{|c|}{$113 b$} & \multicolumn{2}{|l|}{$168 a$} & $128 a$ & \multirow{2}{*}{\multicolumn{2}{|c|}{$\begin{array}{l}1.57 \mathrm{a} \\
1.09 \mathrm{~b}\end{array}$}} & \multicolumn{2}{|c|}{$33 \mathrm{~b}$} \\
\hline Delicious & \multicolumn{2}{|c|}{$122 a$} & \multicolumn{2}{|l|}{$114 \mathrm{~b}$} & $88 \mathrm{~b}$ & & & \multicolumn{2}{|c|}{$40 \mathrm{a}$} \\
\hline \multicolumn{10}{|l|}{ Planting density } \\
\hline High & \multicolumn{2}{|c|}{$98 \mathrm{~b}$} & \multicolumn{2}{|l|}{$106 \mathrm{c}$} & $118 \mathrm{a}$ & \multicolumn{2}{|r|}{$1.27 \mathrm{a}$} & \multicolumn{2}{|c|}{$37 \mathrm{a}$} \\
\hline Medium & \multicolumn{2}{|c|}{$120 \mathrm{ab}$} & \multicolumn{2}{|l|}{$147 b$} & $110 \mathrm{a}$ & \multicolumn{2}{|r|}{$1.35 \mathrm{a}$} & \multicolumn{2}{|c|}{$37 \mathrm{a}$} \\
\hline Low & \multicolumn{2}{|c|}{$134 \mathrm{a}$} & \multicolumn{2}{|l|}{$170 \mathrm{a}$} & $95 \mathrm{~b}$ & \multicolumn{2}{|r|}{$1.37 \mathrm{a}$} & \multicolumn{2}{|c|}{$35 \mathrm{a}$} \\
\hline Treatment $^{\mathrm{y}}$ & Gala & Delicious & Gala & Delicious & & Gala & Delicious & Gala & Delicious \\
\hline BUD & 89 ef & $77 \mathrm{f}$ & $184 a$ & $122 \mathrm{efg}$ & $121 \mathrm{ab}$ & $2.09 \mathrm{a}$ & $1.83 \mathrm{~b}$ & $28 \mathrm{f}$ & $39 c$ \\
\hline $\mathrm{CON}$ & $148 a$ & $148 \mathrm{a}$ & $200 \mathrm{a}$ & $130 \mathrm{def}$ & $125 a b$ & $1.35 \mathrm{c}$ & $0.93 \mathrm{efg}$ & 29 ef & $42 \mathrm{bc}$ \\
\hline $\mathrm{D}+\mathrm{E}-\mathrm{S}$ & $147 a$ & $145 \mathrm{a}$ & $188 \mathrm{a}$ & $156 \mathrm{~b}$ & $131 \mathrm{a}$ & $1.35 \mathrm{c}$ & $1.12 \mathrm{c}-\mathrm{f}$ & $35 \mathrm{cde}$ & 31 def \\
\hline PAC-S & $116 \mathrm{~cd}$ & $134 a b$ & $151 \mathrm{~b}$ & $102 \mathrm{ghi}$ & $97 c$ & $1.36 \mathrm{c}$ & $0.88 \mathrm{~g}$ & $37 \mathrm{~cd}$ & $39 \mathrm{c}$ \\
\hline UNI-S & $108 \mathrm{~cd}$ & $114 \mathrm{~cd}$ & $181 \mathrm{a}$ & $111 \mathrm{fgh}$ & $112 b$ & $1.74 \mathrm{~b}$ & $1.14 \mathrm{~cd}$ & $27 \mathrm{f}$ & 30 def \\
\hline PAC-T & $122 \mathrm{bc}$ & $143 \mathrm{a}$ & $134 \mathrm{cde}$ & $112 \mathrm{e}-\mathrm{h}$ & $94 \mathrm{c}$ & 1.13 cde & $0.89 \mathrm{fg}$ & $41 \mathrm{bc}$ & $42 \mathrm{bc}$ \\
\hline $\mathrm{UNI}-\mathrm{T}$ & 89 ef & $101 \mathrm{de}$ & $148 \mathrm{bcd}$ & $92 \mathrm{hi}$ & $91 \mathrm{c}$ & $1.69 \mathrm{~b}$ & $0.99 \mathrm{~d}-\mathrm{g}$ & 36 cde & $47 a b$ \\
\hline UNI-P & 88 ef & $105 \mathrm{~d}$ & $156 b c$ & $85 \mathrm{i}$ & $92 \mathrm{c}$ & $1.81 \mathrm{~b}$ & $0.95 \mathrm{efg}$ & $29 \mathrm{ef}$ & $50 a$ \\
\hline \multicolumn{10}{|l|}{ F significance } \\
\hline $\mathrm{CV}$ & \multicolumn{2}{|c|}{$*$} & \multicolumn{2}{|l|}{$* *$} & $* *$ & & $* *$ & & \\
\hline $\mathrm{PD}$ & & & $* * *$ & & $*$ & & NS & & \\
\hline TR & & & $* * * *$ & & $* * *$ & & $* * *$ & & \\
\hline $\mathrm{CV} \times \mathrm{PD}$ & & & NS & & NS & & NS & & \\
\hline $\mathrm{CV} \times \mathrm{TR}$ & & & * & & NS & & $* * *$ & & \\
\hline $\mathrm{PD} \times \mathrm{TR}$ & & & $*$ & & NS & & NS & & \\
\hline $\mathrm{CV} \times \mathrm{PD} \times \mathrm{TR}$ & & & NS & & NS & & NS & & \\
\hline
\end{tabular}

${ }^{2}$ High $=1121$ trees $/$ ha; medium $=747$ trees $/$ ha; low $=561$ trees $/$ ha.

${ }^{\text {}} \mathrm{BUD}=$ budded on $\mathrm{M} .7 \mathrm{a} ; \mathrm{CON}=$ tissue-cultured control; $\mathrm{D}+\mathrm{E}-\mathrm{S}=$ daminozide + ethephon sprays; PAC-S = paclobutrazol spray; UNI-S = uniconazole spray; PAC-T = paclobutrazol trunk drench: UNI-T = uniconazole trunk drench; UNI-P = uniconazole trunk paint.

${ }^{\mathrm{Ns}}, *, * * * * *$ Nonsignificant or significant at $P \leq 0.05,0.01$, or 0.001 , respectively. Mean separation for main effect means by Duncan's multiple range test, $P=0.05$, and for interaction means by $t$ test.

\section{Results}

\section{Tree survival}

Tree losses totaled 22, five 'Gala' and 17 'Delicious'. All 'Gala' trees were TC, two dying during the planting year, one dying from fire blight (incited by Erwinia amylovora) in 1986 and two being blown over in 1991 and 1992. For 'Delicious', six dead trees were BUD and the other 11 TC. Seven 'Delicious' trees died within the first 3 years (four BUD, three TC), whereas the other losses were mainly after 1988. Tree loss was not related to planting density or growth regulator treatment.

\section{Vegetative growth}

The early results on lateral shoot length, tree height and crown volume have been reported (Zimmerman and Steffens, 1989; Steffens and Zimmerman, 1989). Later results were consistent with those reports and were in essential agreement with the TCSA data reported below.

Cultivar. 'Gala' trees had larger TCSAs than 'Delicious' after the first three growing seasons, but 'Delicious' trees were significantly larger $(P \leq 0.05)$ after 9 years (Table 2$)$. The annual growth increment, $\Delta$ TCSA, was significantly larger for 'Gala' trees in 1985 and 1986 (data not shown) and for 'Delicious' in 1988 (Table 3).

Planting density. TCSA was significantly affected by planting density only in 1988 (data not shown). Trees at high density had significantly smaller $\Delta$ TCSA than trees at the other two planting densities in 1986 (data not shown), 1987 and 1990 (Table 3).
Interactions between cultivar and planting density were significant for $\Delta$ TCSA only in 1989 (Table 3).

Treatments. PGR treatments, or the effect of budding on M.7a rootstock, significantly affected TCSA every year and $\triangle$ TCSA every year except 1985 (Table 3, data not shown for 1985 and 1986). BUD trees were larger when planted and this was reflected in the TCSA being significantly larger than for TC trees at the end of the first growing season. The difference had disappeared for 'Gala' by the end of the second growing season (1985), but persisted an additional year for 'Delicious'. After that, BUD 'Delicious' trees had the smallest TCSA every year, but 'Gala' trees receiving the UNI-T and UNI-P treatments had TCSA as small as BUD the final 3 years (1990- 1992; data not shown). The final TCSA values (Table 2) show that D+E-S had no effect on vegetative growth as measured by TCSA for either cultivar, that uniconazole had more effect than paclobutrazol, and that the trunk drench and trunk paint treatments were more effective than sprays. The UNI-T and UNI-P treatments reduced growth of 'Gala' so that the final TCSA was the same as for BUD. Final TCSA for BUD trees did not differ among planting densities, but for all other treatments, final TCSA of trees at high density was smaller than that of trees at low density (Fig. la).

Overall, BUD trees tended to have the smallest $\triangle$ TCSA over the years (Table 3) and differences among treatments varied, particularly from 1989 on, depending upon the persistence of the PGR effects and the effects of fruiting on vegetative vigor. Annual growth increment for trees treated with D+E-S was always equal to the largest $\Delta$ TCSA. 
Table 3. Main effects and interactions of cultivar, planting density, and treatment on annual increase in trunk cross-sectional area $\left(\mathrm{cm}^{2}\right)$ after all growth regulator treatments had been applied at least one year.

\begin{tabular}{|c|c|c|c|c|c|c|c|c|}
\hline \multirow[b]{2}{*}{ Factor } & \multicolumn{8}{|c|}{ Year } \\
\hline & 1987 & 1988 & \multicolumn{2}{|c|}{1989} & \multicolumn{2}{|c|}{1990} & 1991 & 1992 \\
\hline \multicolumn{9}{|l|}{ Cultivar } \\
\hline Gala & $15.5 \mathrm{a}$ & $8.6 \mathrm{~b}$ & \multicolumn{2}{|c|}{$19.8 \mathrm{a}$} & \multicolumn{2}{|c|}{$14.2 \mathrm{a}$} & $10.6 \mathrm{a}$ & $15.5 \mathrm{a}$ \\
\hline Delicious & $14.8 \mathrm{a}$ & $13.0 \mathrm{a}$ & \multicolumn{2}{|c|}{$18.6 \mathrm{a}$} & \multicolumn{2}{|c|}{$17.6 \mathrm{a}$} & $15.7 a$ & $19.9 \mathrm{a}$ \\
\hline Planting density & & $(G$ & \multicolumn{2}{|c|}{$(D e l)}$. & & & & \\
\hline High & $11.8 \mathrm{~b}$ & $9.4 \mathrm{a}$ & $17.6 \mathrm{~b}$ & $18.5 \mathrm{~b}$ & \multicolumn{2}{|c|}{$11.1 \mathrm{~b}$} & $10.9 \mathrm{a}$ & $13.5 \mathrm{~b}$ \\
\hline Medium & $16.4 \mathrm{a}$ & $10.5 \mathrm{a}$ & $19.1 \mathrm{~b}$ & $20.0 \mathrm{ab}$ & \multicolumn{2}{|c|}{$16.8 \mathrm{a}$} & $13.6 \mathrm{a}$ & $17.2 \mathrm{ab}$ \\
\hline Low & $17.4 \mathrm{a}$ & $12.4 \mathrm{a}$ & $22.8 \mathrm{a}$ & $17.0 \mathrm{~b}$ & \multicolumn{2}{|c|}{$19.7 \mathrm{a}$} & $14.9 \mathrm{a}$ & $22.3 \mathrm{a}$ \\
\hline \multicolumn{5}{|l|}{ Treatment $^{y}$} & \multicolumn{3}{|c|}{$($ Gala $) \quad($ Del. $)$} & \\
\hline BUD & $10.5 \mathrm{e}$ & $6.7 \mathrm{c}$ & & & $12.2 \mathrm{efg}$ & $7.7 \mathrm{gh}$ & $9.5 b c$ & $10.4 \mathrm{~d}$ \\
\hline $\mathrm{CON}$ & $18.9 \mathrm{a}$ & $15.1 \mathrm{a}$ & & & $25.5 \mathrm{a}$ & $23.6 \mathrm{ab}$ & $17.6 \mathrm{a}$ & $18.6 \mathrm{ab}$ \\
\hline $\mathrm{D}+\mathrm{E}-\mathrm{S}$ & $18.8 \mathrm{a}$ & $15.1 \mathrm{a}$ & & & $22.2 \mathrm{abc}$ & $23.2 \mathrm{ab}$ & $15.2 \mathrm{ab}$ & $22.4 \mathrm{ab}$ \\
\hline $\mathrm{PAC}-\mathrm{S}$ & $17.2 \mathrm{ab}$ & $11.5 \mathrm{~b}$ & & & $14.3 \mathrm{def}$ & $18.3 \mathrm{bcd}$ & $15.3 \mathrm{ab}$ & $20.0 \mathrm{ab}$ \\
\hline UNI-S & $16.3 \mathrm{bc}$ & $11.5 \mathrm{~b}$ & & & $10.9 \mathrm{fgh}$ & $12.3 \mathrm{efg}$ & $12.2 \mathrm{abc}$ & $17.8 \mathrm{abc}$ \\
\hline PAC $-\mathrm{T}$ & $14.2 \mathrm{~cd}$ & $11.3 \mathrm{~b}$ & & & $15.6 \mathrm{def}$ & $22.2 \mathrm{abc}$ & $14.0 \mathrm{abc}$ & $23.8 \mathrm{a}$ \\
\hline UNI-T & $12.8 \mathrm{de}$ & $7.9 \mathrm{c}$ & & & $7.5 \mathrm{gh}$ & $16.6 \mathrm{cde}$ & $8.9 \mathrm{c}$ & $16.4 \mathrm{bcd}$ \\
\hline UNI-P & $12.7 \mathrm{de}$ & $7.1 \mathrm{c}$ & & & $5.7 \mathrm{~h}$ & 15.9 def & $12.3 a b c$ & $12.1 \mathrm{~cd}$ \\
\hline \multicolumn{9}{|l|}{ F significance } \\
\hline $\mathrm{CV}$ & NS & $*$ & \multicolumn{2}{|c|}{ NS } & \multicolumn{2}{|c|}{ NS } & NS & NS \\
\hline PD & $*$ & NS & \multicolumn{2}{|c|}{ NS } & \multicolumn{2}{|l|}{$*$} & NS & NS \\
\hline TR & $* * *$ & $* * *$ & \multicolumn{2}{|c|}{$* * *$} & \multicolumn{2}{|c|}{$* * *$} & $*$ & $* * *$ \\
\hline $\mathrm{CV} \times \mathrm{PD}$ & NS & NS & \multicolumn{2}{|c|}{ * } & \multicolumn{2}{|c|}{ NS } & NS & NS \\
\hline $\mathrm{CV} \times \mathrm{TR}$ & NS & NS & \multicolumn{2}{|c|}{ NS } & \multicolumn{2}{|c|}{$* *$} & NS & NS \\
\hline $\mathrm{PD} \times \mathrm{TR}$ & $*$ & NS & \multicolumn{2}{|c|}{ NS } & \multicolumn{2}{|c|}{ NS } & NS & NS \\
\hline $\mathrm{CV} \times \mathrm{PD} \times \mathrm{TR}$ & NS & NS & \multicolumn{2}{|c|}{ NS } & \multicolumn{2}{|c|}{ NS } & NS & NS \\
\hline
\end{tabular}

${ }^{\bar{T}}$ High $=1121$ trees/ha; medium $=747$ trees/ha; low $=561$ trees $/$ ha.

'BUD = budded on M.7a; CON = tissue-cultured control; D+E-S = daminozide + ethephon sprays; PAC-S = paclobutrazol spray; UNI-S = uniconazole spray; PAC-T = paclobutrazol trunk drench: UNI-T = uniconazole trunk drench; UNI-P = uniconazole trunk paint.

NS,***,***Nonsignificant or significant at $P \leq 0.05,0.01$ or 0.001 , respectively. Mean separation within a year among main effect means by Duncan's multiple range-test, $P=0.05$, and among interaction means by $t$ test.

Note that for most years starting in 1988, $\Delta$ TCSA for PAC-T-treated trees was significantly larger than for the UNI-T- and UNI-P-treated ones, but was not significantly different from the PAC-S- and UNI$\mathrm{S}$-treated ones. This result indicates that the PAC-T treatment was less effective in controlling tree vigor than the UNI-T and UNI-P treatments. The significant treatment $\times$ planting density interaction that occurred in 1986 (data not shown) and 1987 (Fig. 1b) reflected the fact that growth regulator applications were started on trees in the high density planting 1 year earlier (1986) than on trees in the lower densities (Table 1).

\section{Flowering}

Cultivar. Flowering of 'Gala' trees was higher than for 'Delicious' trees every year except 1989 (Table 4). The highest number of flower clusters per tree occurred in 1991.

Planting density. The number of flower clusters per tree differed significantly among planting densities from 1988 through 1992 (Table 4). However, the cultivar $\times$ planting density interaction was highly significant during 1988-1990 (Table 4).

Treatments. BUD trees had a few scattered flowers in 1985 and all flowered in 1986; TC trees (all treatments) began flowering in 1986 (data not shown). Both the effect of PGR treatment and the cultivar $\mathrm{x}$ treatment interaction were also highly significant every year (Table 4). BUD trees had more flower buds than CON 6 of 7 years for 'Gala' and 5 of 7 years for 'Delicious'. Growth retardants had little impact on increasing flowering of the TC trees of 'Gala' until 1990, when UNI-S and to a lesser extent UNI-T and UNI$P$ increased the number of flower buds. The effect persisted in 1991 for UNI-S. In 1991 and 1992, the D+E-S treatment also had a considerable effect on increasing flowering. For 'Delicious', UNI$\mathrm{S}$ increased flowering above the CON trees in 1989, but only D+E$S$ had this effect in succeeding years, particularly 1990 and 1991 (Table 4$)$. The planting density $\times$ treatment interaction was significant only in 1988 and 1989. In 1988, the PAC-T-treated trees at high density had very few flower clusters and UNI-P-treated trees at high density had as many clusters as trees at the lower densities (Fig. 2a). In 1989, trees in the UNI-T and UNI-P treatments at high density had very few flowers in relation to the other planting densities and trees in the BUD, UNI-S, UNI-T, and UNI-P treatments at medium density had as many as, or more, flowers than trees at low density (Fig. 2b). The interaction between cultivar, planting density and treatments in 1990 (Fig. 3a) can be attributed to the very low numbers of flower clusters on the 'Delicious' trees treated with triazole PGRs at all planting densities, and the increased flowering of 'Gala' trees in some of the same treatments, especially at the lower planting densities.

\section{Fruiting}

Cultivar. 'Gala' trees yielded significantly more fruit than 'Delicious' in 1987, 1988, and 1990 (Table 5), but differences other years were not significant. Cumulative yield per tree or per hectare was significantly higher for 'Gala' than for 'Delicious' (Table 2). Average weight per fruit was significantly higher for 'Delicious' than for 'Gala' (data not shown). Fruit set was significantly higher for 'Gala' than for 'Delicious' in 1987 and 1989, but not other years (data not shown). 


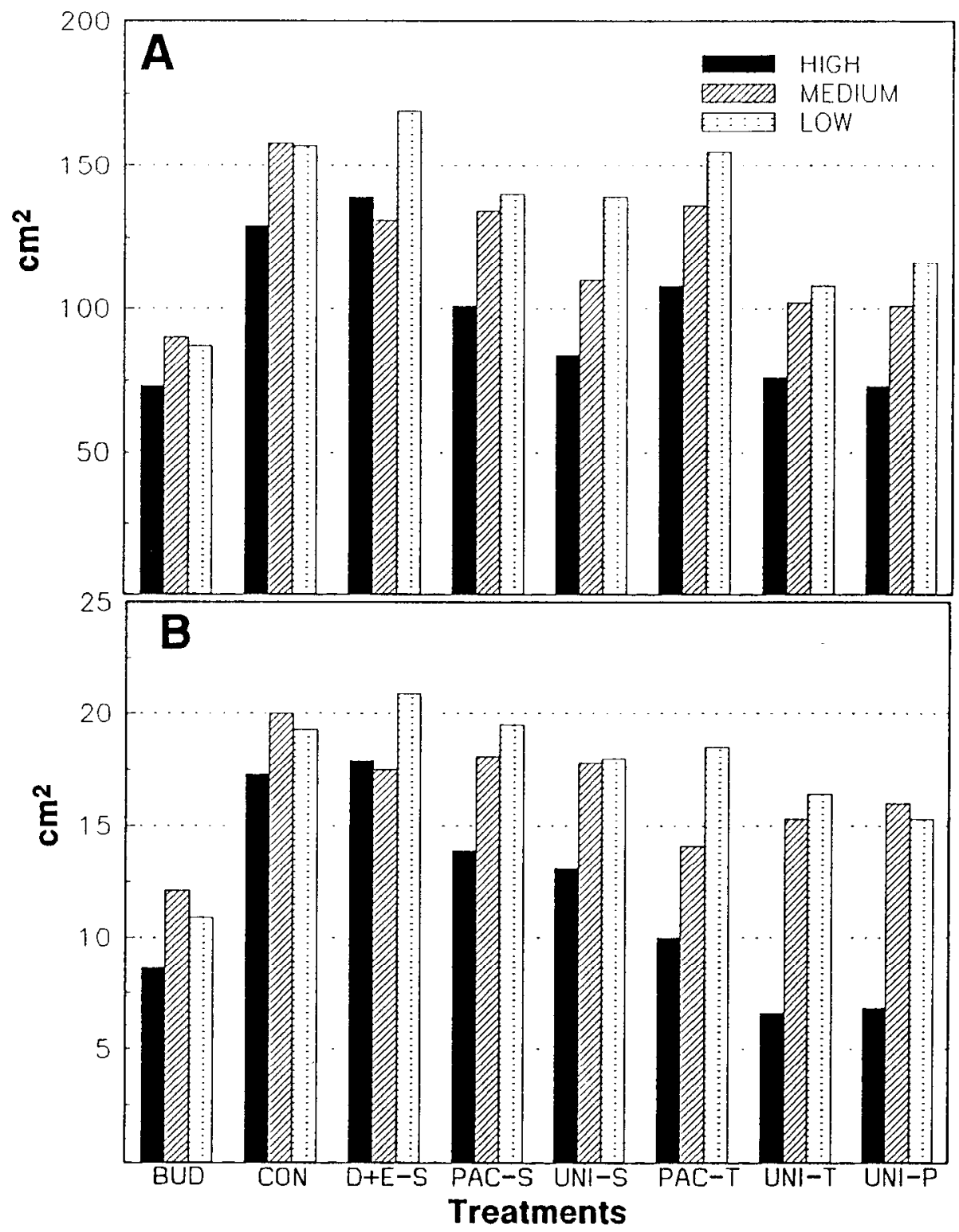

Fig. 1. Significant interaction between planting density and growth regulator treatments for (A) final trunk cross-sectional area (see Table 2) and (B) increase in trunk cross-sectional area in 1987 (see Table 3).

Planting density. Fruit yield per tree increased as planting density decreased from 1988 through 1992 (Table 5). Cumulative yield per tree increased as planting density decreased, but cumulative yield per hectare was significantly lower for trees at the lowest planting density (Table 2). Planting density had no effect on fruit size and affected fruit set only one year, when fruit set increased as planting density increased (data not shown).

The significant cultivar $\times$ planting density interaction in 1988 and 1990 resulted from yield per tree increasing as planting density decreased for 'Gala', whereas yield did not differ among planting densities for 'Delicious' (Table 5).

Yield per hectare increased significantly as planting density increased in 1986- 1989 and $1991(P \leq 0.001$ 1989; $P \leq 0.01 \quad 1988$; $P \leq 0.05$ 1986-87, 1991; data not shown). The only exception was in 1989, when trees at the medium density had the highest per hectare yield. The cultivar $\mathrm{x}$ planting density interaction was significant only in $1989(P \leq 0.05)$, when the per hectare yield of 'Delicious' trees was $50 \%$ higher (16.6 vs. 11.1 t) at medium density than at high density.

Treatments. BUD trees had highest yields, or equal to highest, every year except 1990 and 1992, when CON trees had yields significantly higher than BUD (Table 5; yield per tree in 1986 and yield per hectare data not shown). Trees receiving the D+E-S treatment had a significantly higher cumulative yield per tree than BUD trees (Table 2), but this effect resulted from the responsiveness of the 'Delicious' trees to this treatment. All other PGR treatments had lower cumulative yields per tree than CON and $\mathrm{D}+\mathrm{E}-\mathrm{S}$ (Table 2) and per hectare than D+E-S (Table 2). Fruit size was generally inversely proportional to yield. Size of fruit from BUD and CON trees was equal every year except 1991, when fruit from BUD trees were larger; fruit from trees treated with D+E-S tended to be smallest every year (data not shown). BUD trees had the lowest fruit set, whereas those treated with paclobutrazol generally had the highest set (data not shown).

The most striking difference between cultivars in cumulative yield per tree was with treatment D+E-S, which was much more 


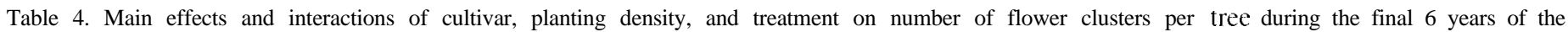
experiment in which most trees of both cultivars flowered each year.

\begin{tabular}{|c|c|c|c|c|c|c|c|c|c|c|c|}
\hline \multirow[b]{2}{*}{ Factor } & \multicolumn{11}{|c|}{ Year } \\
\hline & \multicolumn{2}{|c|}{1987} & \multicolumn{2}{|c|}{1988} & \multicolumn{2}{|c|}{1989} & \multicolumn{2}{|c|}{ 1990) } & 1991 & \multicolumn{2}{|r|}{1992} \\
\hline \multicolumn{12}{|l|}{ Cultivar } \\
\hline Galat & \multicolumn{2}{|c|}{$313 a$} & \multicolumn{2}{|c|}{$628 \mathrm{a}$} & \multicolumn{2}{|c|}{$183 \mathrm{~b}$} & \multicolumn{2}{|c|}{$816 a$} & $868 a$ & \multicolumn{2}{|r|}{$497 a$} \\
\hline Delicious & \multicolumn{2}{|c|}{$64 \mathrm{~b}$} & \multicolumn{2}{|c|}{$161 \mathrm{~b}$} & \multicolumn{2}{|c|}{$413 a$} & \multicolumn{2}{|c|}{$343 \mathrm{~b}$} & $734 \mathrm{a}$ & \multirow{2}{*}{\multicolumn{2}{|c|}{$320 \mathrm{a}$}} \\
\hline Planting density & & & (Gala) & $\left.(D)_{\mathcal{C}} l\right)$ & (Gala) & $(D e l)$ & $(G a l a)$ & $(D e l)$. & & & \\
\hline High & \multicolumn{2}{|c|}{$202 \mathrm{a}$} & $419 c$ & $189 \mathrm{~d}$ & $161 \mathrm{~b}$ & $196 \mathrm{~b}$ & $623 c$ & $333 \mathrm{~d}$ & $565 c$ & & $353 \mathrm{~b}$ \\
\hline Medium & \multicolumn{2}{|c|}{$201 \mathrm{a}$} & $682 \mathrm{~b}$ & $146 \mathrm{~d}$ & $191 \mathrm{~b}$ & 498 a & $856 \mathrm{~b}$ & $362 \mathrm{~d}$ & $832 \mathrm{~b}$ & & $374 \mathrm{~b}$ \\
\hline Low & \multicolumn{2}{|c|}{$164 a$} & $782 \mathrm{a}$ & $147 \mathrm{~d}$ & $196 \mathrm{~b}$ & $546 a$ & $969 a$ & $335 \mathrm{~d}$ & $1004 a$ & & $499 a$ \\
\hline Treatment ${ }^{y}$ & (Gala) & $(D c l)$. & (Gala) & $(D e l)$ & (Gala) & $(D e l)$. & $(G a l a)$ & $(D e l)$. & & (Gala) & $(D e l)$. \\
\hline BUD & $934 a$ & $264 b c$ & $980 \mathrm{a}$ & $347 c$ & $285 \mathrm{cdc}$ & $577 a$ & $810 b c$ & $429 \mathrm{fg}$ & $1015 a$ & $695 \mathrm{ab}$ & $287 \mathrm{e}-\mathrm{i}$ \\
\hline $\mathrm{CON}$ & $212 \mathrm{bcd}$ & $24 e$ & $509 \mathrm{~cd}$ & $72 \mathrm{~g}$ & $218 \mathrm{def}$ & $319 \mathrm{bcd}$ & $657 \mathrm{de}$ & $453 \mathrm{fg}$ & $76.3 \mathrm{~b}$ & 559 bcd & $596 \mathrm{bc}$ \\
\hline $\mathrm{D}+\mathrm{E}-\mathrm{S}$ & $253 \mathrm{bcd}$ & $29 \mathrm{e}$ & $664 \mathrm{~b}$ & $146 \mathrm{fg}$ & $280 \mathrm{cde}$ & $369 \mathrm{bc}$ & $805 b c$ & $628 \mathrm{de}$ & $990 \mathrm{a}$ & $806 a$ & $695 \mathrm{ab}$ \\
\hline $\mathrm{PAC}-\mathrm{S}$ & $191 \mathrm{~d}$ & $26 e$ & $602 \mathrm{bcd}$ & $85 \mathrm{~g}$ & $1191 \mathrm{~g}$ & $434 \mathrm{~b}$ & $699 \mathrm{~cd}$ & $219 \mathrm{~h}$ & $638 \mathrm{~b}$ & $344 \mathrm{e}-\mathrm{h}$ & 218 ghi \\
\hline UNI-S & $275 b$ & $35 \mathrm{c}$ & $614 b c$ & $131 \mathrm{gg}$ & 220 def & $618 a$ & $1225 a$ & $309 \mathrm{gh}$ & $979 \mathrm{a}$ & $391 \mathrm{~d}-\mathrm{g}$ & $218 \mathrm{ghi}$ \\
\hline PAC-T & $229 \mathrm{bcd}$ & $36 \mathrm{e}$ & $499 d$ & $137 \%$ & $72 y$ & $183 \mathrm{cg}$ & $526 \mathrm{el}$ & $256 \mathrm{~h}$ & $705 \mathrm{~b}$ & 349 e-n & $241 \mathrm{f}-\mathrm{i}$ \\
\hline UNI-T & $201 \mathrm{~cd}$ & $58 \mathrm{e}$ & $630 \mathrm{~b}$ & $198 f^{\circ}$ & $1111 \mathrm{~g}$ & $427 b$ & $950 \mathrm{~b}$ & $217 \mathrm{~h}$ & $592 \mathrm{~b}$ & $405 \mathrm{def}$ & $126 i$ \\
\hline UNI-P & $212 \mathrm{bcd}$ & $40 \mathrm{e}$ & $524 \mathrm{~cd}$ & $172 \mathrm{fg}$ & $158 \mathrm{elg}$ & $378 \mathrm{bc}$ & $854 \mathrm{~b}$ & $237 \mathrm{~h}$ & $737 b$ & $427 \mathrm{cde}$ & $175 \mathrm{hi}$ \\
\hline \multicolumn{12}{|l|}{ F significance } \\
\hline $\mathrm{CV}$ & \multicolumn{2}{|c|}{$*: * *$} & \multicolumn{2}{|c|}{$* *$} & \multicolumn{2}{|c|}{$* *$} & \multicolumn{2}{|c|}{$*$} &.$N S$ & & NS \\
\hline PD & \multicolumn{2}{|c|}{ NS } & \multicolumn{2}{|c|}{ 水* } & \multicolumn{2}{|c|}{$* *$} & \multicolumn{2}{|c|}{$* *$} & $* * *$ & & * \\
\hline $\mathrm{TR}$ & $* 3$ & & $\%$ & & & & & & $* * *$ & & $* * *$ \\
\hline $\mathrm{CV} \times \mathrm{PD}$ & $\mathrm{N}$ & & : & & & & & & NS & & NS \\
\hline $\mathrm{CV} \times \mathrm{TR}$ & $* *$ & & $*$ & & & & & & NS & & $*$ \\
\hline $\mathrm{PD} \times \mathrm{TR}$ & $\mathrm{N}$ & & . & & & & & & NS & & NS \\
\hline $\mathrm{CV} \times \mathrm{PD} \times \mathrm{TR}$ & $v$ & & $N$ & & & & & & NS & & NS \\
\hline
\end{tabular}

${ }^{2} \mathrm{High}=1121$ trees $/$ ha; medium $=747$ trees $/$ ha; low $=561$ trees $V$ ha.

${ }^{y} \mathrm{BUD}=$ budded on M.7a: CON = tissue-cultured control: D+E-S = daminozidc +ethcphon sprays; PAC-S = paclobutrazol spray; UNI-S = uniconazolc spray; PAC-T = paclobutrazol trunk drench: UNI-T = uniconade trunk drench; UNI-P = uniconazolc trunk paint.

Ns,*,*****Nonsignificant or significant at $P \leq 0.05,0.01$ or 0.001 , respectively. Mean separation within a year among main effect means by Duncan's multiple range test. $P=0.05$. and among interaction means by $t$ testing.

effective in increasing yields of 'Delicious' than of 'Gala' (Table 2). The other PGR treatments all reduced yield below both the CON and BUD controls, except for UNI-S, and the amount of reduction varied between cultivars.

Trees in all treatments except PAC-S had lower cumulative yields at high density than at medium density and trees in treatments CON, D+E-S, PAC-S. and UNI-S had higher yields at low density than at medium density. whereas yields did not differ between low and medium density for the other four treatments (Table 2, Fig. 4a). In 1989, this interaction occurred because yields were particularly low at high density for trees in treatments UNI$\mathrm{P}$, UNI-T, and PAC-T and high at low density for trees in treatments CON and D+E-S (Fig. 4b). In 1991, essentially no difference in yield existed between trees at medium and low planting density for the BUS, UNI-T, and UNI-P treatments, which was in striking contrast to the others (Fig. 4c). The cultivar $\times$ planting density $\times$ treatment interaction in 1990 (Fig. 3c) can be attributed to the consistently higher yields for 'Gala' in comparison with 'Delicious' except for trees in the D+E-S treatment and a general increase in yield with decrease in planting density for 'Gala', whereas planting density had little effect on yield of 'Delicious', except for treatment D+E-S. In 1991, this three-factor interaction was characterized by very high yields for 'Gala' at low planting density in treatments CON, UNI-S, and D+E-S, smaller overall differences in yield between 'Gala' and 'Delicious' than in 1990, and more tendency for 'Delicious' yields to increase with decreasing planting density (Fig. 3d).

\section{Yield efficiency}

Cultivar and planting density. 'Gala' had a higher yield efficiency than 'Delicious', a reflection of smaller tree size and higher yield (Table 2). Planting density did not affect yield efficiency and the interaction between cultivar and planting density was not significant.

Treatments. Yield efficiency was affected significantly by treatment, and the cultivar $\times$ treatment interaction was significant (Table 2). BUD trees had significantly higher efficiency than any other treatment for both cultivars. For 'Gala', all uniconazoletreated trees had significantly higher efficiency than those receiving the remaining four treatments. In contrast, in 'Delicious' few significant differences occurred among the remaining treatments (Table 2), although trees in the UNI-S and D+E-S treatments had the highest efficiencies.

\section{Mean bienniality index}

Cultivar and planting density. 'Gala' had a significantly lower tendency toward biennial bearing than did 'Delicious' (Table 2). Planting density had no effect on the bienniality index, nor was the interaction between cultivar and planting density significant.

Treatments. The tendency for biennial bearing of 'Gala' was significantly less for trees in the BUD and UNI-S treatments than for those in D+E-S, PAC-S, PAC-T, and UNI-T, whereas trees in the PAC-T and PACX treatments had significantly more tendency than those in BUD, CON, UNI-S, and UNI-P (Table 2). For 'Delicious', trees in treatments UNI-S and D+E-S had the least tendency toward 

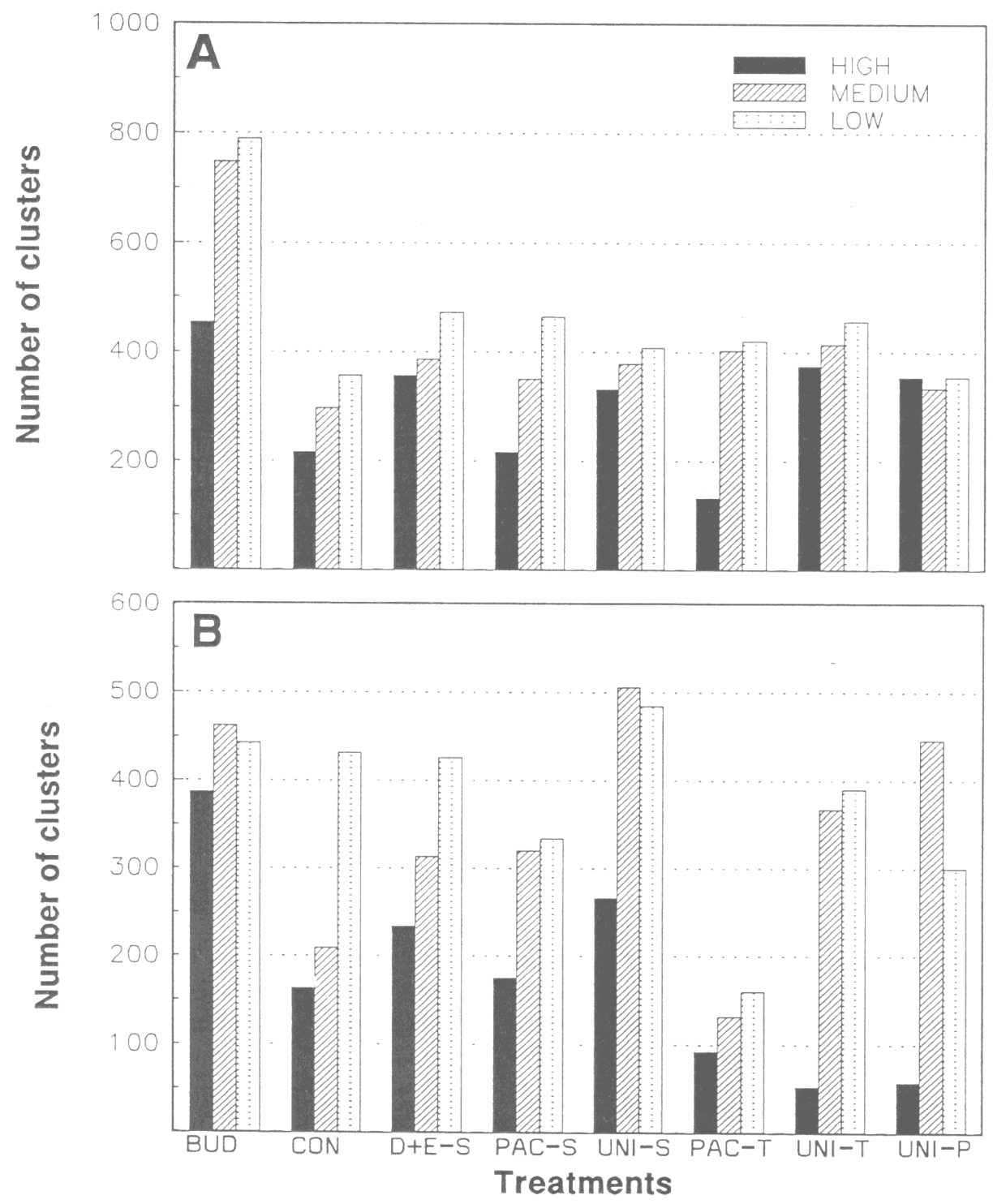

Fig. 2. Significant interaction (see Table 4) between planting density and growth regulator treatments for number of flower clusters in (A) 1988 and (B) 1989.

biennial bearing, those in UN-P and UNI-T had the most and those in the other treatments were intermediate (Table 2). The main influence of planting density on the three-factor interaction appeared to be the differential response of the two cultivars for trees in treatments PAC-T, UNI-T, and UNI-P (Fig. 3b).

\section{Burrknots}

Burrknots were first noted on 'Gala' TC trees in this experiment in the second growing season. They developed extensively on many trees in the following years. At the end of the experiment, they were found on all trees of 'Gala', with $27 \%$ of the trees rated as low intensity, $46 \%$ as medium and $28 \%$ as high; $97 \%$ of the trees had burrknots on both the lower part of the trunk and throughout the crown, while the remaining 3\% had none on the lower part of the trunk. For 'Delicious', 24\% of the trees were affected and all were rated as low intensity; $14 \%$ of the affected trees had burrknots on the lower trunk, $80 \%$ on branches or the upper part of the trunk and $7 \%$ in both locations. Since none of the 'Delicious' BUD trees had burr-knots and $75 \%$ of the 'Gala' BUD trees were rated low and the remaining $25 \%$ medium for burrknot intensity, it is clear that tissue culture increased the formation of burrknots. For 'Deli- cious', three to eight (12\%-33\%) of the 24 TC trees in each treatment (middle two trees per four-tree plot at all planting densities) had burrknots with most treatments having at least seven of 24 trees affected. The effect of PGR treatment was difficult to evaluate, but half of the PAC-T treated trees were in the high intensity category, whereas for other PGR treatments $17 \%$ to $39 \%$ of the trees were in this category. Overall, most trees were rated as medium intensity.

\section{Discussion}

Tree survival. A clear distinction in tree losses was observed between 'Gala' and 'Delicious' in this experiment. No BUD trees of 'Gala' were lost whereas $12 \%$ of BUD trees of 'Delicious' were lost in 9 years. The latter result was comparable to the $19 \%$ loss in 13 years of 'Blaxtayman' on M.7 reported by Funt et al. (1987). The percentage of TC trees lost was low: $1.3 \%$ in 'Gala' and 3.3\% in 'Delicious'. These losses were lower than those reported for 'Blaxtayman' on seedling and MM.111 rootstocks (<7\%) (Funt et al., 1987) and for several cultivars on seedling rootstocks or TC (Zimmerman and Miller, 1991). Much higher losses were reported on M.26 and M.9 and somewhat higher on MM.106 (Funt et al. 
1987). Funt et al. (1987) state that tree loss is the factor causing the greatest reduction in revenue in commercial production. Thus, the high survival rate of TC trees should be considered when evaluating the economic potential of these trees.

Comparison of BUD and CON trees. BUD trees were larger initially, but $\mathrm{CON}$ trees grew more vigorously, equaling BUD trees in $\triangle$ TCSA after the second growing season and exceeding them after the third (Table 3 ). This vigor was manifested also in TCSA, height, spread, canopy volume and average shoot length (Zimmerman and Steffens, 1989). Similar results have been reported with other cultivars (Larsen and Higgins, 1993; Quamme and Brownlee, 1993; Rosati and Gaggioli, 1987, 1989; Zimmerman and Miller, 1991).

Although BUD 'Delicious' trees had more flowers than the CON trees 3 out of 4 years after flowering was initiated (Table 4), fruit yield per BUD tree exceeded that of CON in only 1 year (Table 5); yields for 'Gala' BUD and CON trees did not differ. The results here with Triple Red 'Delicious' contrast with those of Larsen and Higgins (1993) who established an experiment with Royal Red 'Delicious' (a strain indistinguishable from 'Triple Red Delicious', R. Stouffer, personal communication) at the same time that this experiment was established. Yields of 'Delicious' obtained here for TC trees were almost double those reported by Larsen and Higgins (1993) through 1991 (65 vs. $33 \mathrm{~kg} /$ tree) and about 25\% higher than those reported for BUD trees (75 vs. $59 \mathrm{~kg} /$ tree). Yields of 'Gala' reported here are comparable with those found at another planting in western Maryland (C.S. Walsh, personal communication).

The greater vigor of the CON trees as well as their later fruiting resulted in decreased cumulative yield efficiency in comparison with BUD trees (Table 2), as has been reported previously (Larsen and Higgins, 1993; Quamme and Brownlee, 1993; Rosati and Gaggioli, 1987, 1989; Zimmerman and Miller, 1991). The magnitude of this difference has varied depending upon cultivar, cultural practices, site and possibly other factors. However, no difference in bienniality was noted between the BUD and CON trees in this experiment (Table 2).

Vegetative growth. By the end of the 9-year experiment, TCSA of 'Gala' trees was smaller than for 'Delicious' trees for three of the five triazole treatments (Table 2), suggesting that growth of 'Gala' trees was more readily controlled than that of 'Delicious'. The TCSAs of UNI-T- and UNI-P-treated 'Gala' trees were similar to that of the untreated BUD 'Gala' trees, but none of the treatments applied to TC 'Delicious' trees resulted in a TCSA as small as that of BUD 'Delicious' trees (Table 2). TCSA of trees growing at the highest density was smaller (except for treatments BUD and D+ES) than for trees growing at both the medium and low planting densities (Fig. la). The uniconazole treatments were especially effective in reducing TCSA of the high density trees. Generally, uniconazole was more effective than paclobutrazol in controlling tree size, but both triazoles were more effective as planting density increased. Although the most effective treatments for reducing TCSA were UNI-T and UNI-P (Table 2), the vigor of some trees in these treatments, especially at the highest density, was so depressed that their long term survival appeared to be at risk (Steffens and Zimmerman, 1990). A more reasonable overall pattern of size control of TC trees as measured by TCSA was obtained with the PAC-S and PAC-T treatments (Table 2). The TCSA and $\Delta$ TCSA (Table 3) measurements reflected the general growth pattern of the trees and followed the growth patterns shown by height and crown volume measurements (data not shown; see Steffens and Zimmerman, 1989, 1990).

Flowering and fruiting. After 'Gala' TC trees started to flower to their full potential in 1988 , they continued to do so for the
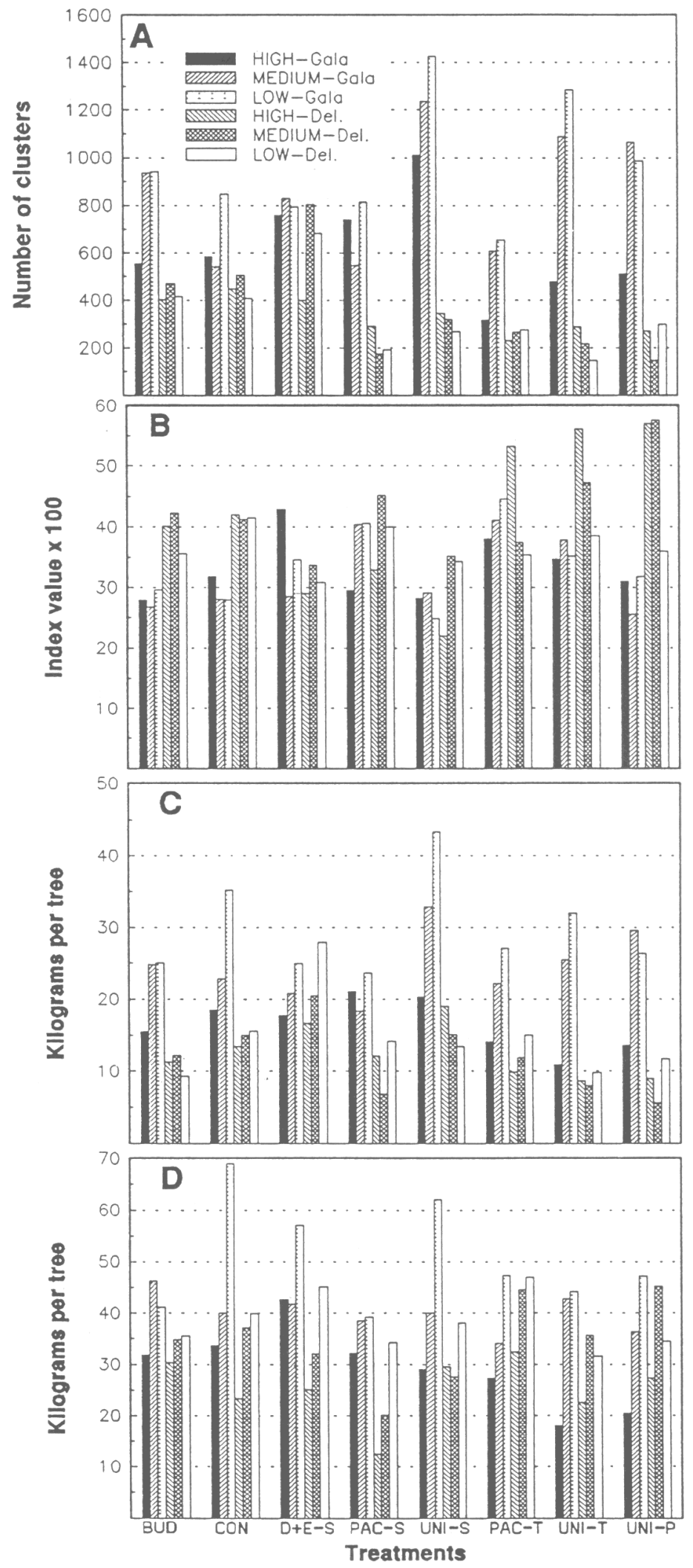

Fig. 3. Significant interaction among cultivar, planting density and growth regulator treatments for (A) number of flower clusters in 1990 (see Table 4). (B) mean bienniality index (see Table 2), and yield per tree in (C) 1990 and (D) 1991 (see. Table 5).

remaining years of the experiment, except 1989 when flowering and yield were reduced somewhat. The D+E-S treatment tended to 
Table 5. Main effects and interactions of cultivar, planting density, and treatment on yield $(\mathrm{kg})$ of fruit per tree during the final 6 years in which most trees of both cultivars flowered each year.

\begin{tabular}{|c|c|c|c|c|c|c|c|c|c|}
\hline \multirow[b]{2}{*}{ Factor } & \multicolumn{9}{|c|}{ Year } \\
\hline & 1987 & \multicolumn{2}{|c|}{1988} & \multicolumn{2}{|c|}{1989} & \multicolumn{2}{|c|}{1990} & 1991 & 1992 \\
\hline \multicolumn{10}{|l|}{ Cultivar } \\
\hline Gala & $8.6 \mathrm{a}$ & \multicolumn{2}{|c|}{$21.7 \mathrm{a}$} & \multicolumn{2}{|c|}{$18.6 \mathrm{a}$} & \multicolumn{2}{|c|}{$23.6 \mathrm{a}$} & $40.2 \mathrm{a}$ & \multirow{3}{*}{$\begin{array}{l}59.2 \mathrm{a} \\
49.2 \mathrm{a}\end{array}$} \\
\hline Delicious & $1.9 \mathrm{~b}$ & \multicolumn{2}{|c|}{$6.5 \mathrm{~b}$} & \multirow{2}{*}{\multicolumn{2}{|c|}{$18.4 \mathrm{a}$}} & & $9 \mathrm{~b}$ & \multirow[t]{2}{*}{$32.5 \mathrm{a}$} & \\
\hline Planting density ${ }^{z}$ & & (Gala) & (Del.) & & & (Gala) & (Del.) & & \\
\hline High & $5.8 \mathrm{a}$ & $17.1 \mathrm{c}$ & $7.3 \mathrm{~d}$ & \multicolumn{2}{|c|}{$12.0 \mathrm{~b}$} & $16.5 \mathrm{c}$ & $12.5 \mathrm{~d}$ & $27.2 \mathrm{c}$ & $42.9 \mathrm{c}$ \\
\hline Medium & $6.9 \mathrm{a}$ & $22.5 \mathrm{~b}$ & $6.2 \mathrm{~d}$ & \multicolumn{2}{|c|}{$20.8 \mathrm{a}$} & $24.6 \mathrm{~b}$ & $11.9 \mathrm{~d}$ & \multirow{2}{*}{$\begin{array}{l}37.3 \mathrm{~b} \\
44.6 \mathrm{a}\end{array}$} & $52.2 \mathrm{~b}$ \\
\hline Low & $8.1 \mathrm{a}$ & $25.6 \mathrm{a}$ & $5.9 \mathrm{~d}$ & \multicolumn{2}{|c|}{$22.5 \mathrm{a}$} & $29.7 \mathrm{a}$ & $14.6 \mathrm{~cd}$ & & $67.4 \mathrm{a}$ \\
\hline \multicolumn{2}{|l|}{ Treatment ${ }^{y}$} & (Gala) & (Del.) & (Gala) & (Del.) & (Gala) & (Del.) & (Gala) (Del.) & (Gala) (Del.) \\
\hline BUD & $7.4 \mathrm{a}$ & $23.9 \mathrm{a}$ & $9.5 \mathrm{de}$ & $24.6 \mathrm{ab}$ & $20.1 \mathrm{bc}$ & $21.6 \mathrm{~b}$ & $10.9 \mathrm{~cd}$ & 39.7 bcd 33.5 de & 59.1 bcd $49.2 \mathrm{de}$ \\
\hline $\mathrm{CON}$ & $6.9 \mathrm{a}$ & $25.4 \mathrm{a}$ & $2.0 \mathrm{~g}$ & $28.9 \mathrm{a}$ & $15.0 \mathrm{~cd}$ & $25.5 \mathrm{~b}$ & $14.7 \mathrm{c}$ & $47.6 \mathrm{a} \quad 33.4 \mathrm{de}$ & $64.0 \mathrm{bc} \quad 64.6 \mathrm{bc}$ \\
\hline $\mathrm{D}+\mathrm{E}-\mathrm{S}$ & $6.1 \mathrm{a}$ & $23.0 \mathrm{ab}$ & $4.3 \mathrm{fg}$ & $25.2 \mathrm{ab}$ & $15.0 \mathrm{~cd}$ & $21.4 \mathrm{~b}$ & $21.7 \mathrm{~b}$ & 34.1 de & $68.7 \mathrm{ab} \quad 81.3 \mathrm{a}$ \\
\hline PAC-S & $6.7 \mathrm{a}$ & $20.1 \mathrm{bc}$ & $5.1 \mathrm{fg}$ & $11.3 \mathrm{de}$ & $24.7 \mathrm{ab}$ & $21.0 \mathrm{~b}$ & $11.0 \mathrm{~cd}$ & 36.6 cde $22.2 \mathrm{f}$ & 54.2 cde 41.6 ef \\
\hline UNI-S & $7.1 \mathrm{a}$ & $25.2 \mathrm{a}$ & $6.6 \mathrm{ef}$ & $27.1 \mathrm{a}$ & $26.3 \mathrm{ab}$ & $32.2 \mathrm{a}$ & $15.8 \mathrm{c}$ & $43.7 \mathrm{ab} \quad 31.9 \mathrm{e}$ & 43.7 e $\quad 40.2$ ef \\
\hline PAC-T & $6.3 \mathrm{a}$ & $16.9 \mathrm{c}$ & $7.3 \mathrm{def}$ & $6.0 \mathrm{e}$ & $14.1 \mathrm{~cd}$ & $21.1 \mathrm{~b}$ & $12.3 \mathrm{~cd}$ & 36.2 cde $41.3 \mathrm{abc}$ & $45.1 \mathrm{e} \quad 43.5 \mathrm{e}$ \\
\hline UNI-T & $6.1 \mathrm{a}$ & $19.5 \mathrm{bc}$ & $10.5 \mathrm{~d}$ & $11.0 \mathrm{de}$ & $17.6 \mathrm{c}$ & $22.8 \mathrm{~b}$ & $8.8 \mathrm{~d}$ & 35.0 cde 29.9 e & $52.2 \mathrm{cde} 28.4 \mathrm{fg}$ \\
\hline UNI-P & $7.7 \mathrm{a}$ & $19.8 \mathrm{bc}$ & $6.7 \mathrm{ef}$ & $14.6 \mathrm{~cd}$ & $14.7 \mathrm{~cd}$ & $23.2 \mathrm{~b}$ & $8.7 \mathrm{~d}$ & 34.6 cde 34.0 de & 53.7 cde $24.4 \mathrm{~g}$ \\
\hline \multicolumn{10}{|l|}{ F significance } \\
\hline $\mathrm{CV}$ & $* *$ & \multicolumn{2}{|c|}{ * } & \multicolumn{2}{|c|}{ NS } & \multicolumn{2}{|r|}{$*$} & NS & NS \\
\hline PD & NS & \multicolumn{2}{|c|}{$*$} & \multicolumn{2}{|c|}{$* * *$} & \multicolumn{2}{|c|}{$* *$} & $* * *$ & $* *$ \\
\hline $\mathrm{TR}$ & $* *$ & & * & & k* & & $* *$ & $* * *$ & $* * *$ \\
\hline $\mathrm{CV} \times \mathrm{PD}$ & NS & & & & IS & & $*$ & NS & NS \\
\hline $\mathrm{CV} \times \mathrm{TR}$ & NS & & & & k* & & $* *$ & $* * *$ & $*$ \\
\hline $\mathrm{PD} \times \mathrm{TR}$ & NS & & & & $*$ & & NS & * & NS \\
\hline $\mathrm{CV} \times \mathrm{PD} \times \mathrm{TR}$ & NS & & & & $S$ & & $*$ & $*$ & NS \\
\hline
\end{tabular}

${ }^{2}$ High $=1121$ trees/ha; medium $=747$ trees/ha; low $=561$ trees $/$ ha.

'BUD = budded on M.7a; CON = tissue-cultured control; D+E-S = daminozide + ethephon sprays; PAC-S = paclobutrazol spray; UNI-S = uniconazole spray; PAC-T $=$ paclobutrazol trunk drench; UNI-T $=$ uniconazole trunk drench; UNI-P $=$ uniconazole trunk paint.

ss, $*, * * * * *$ Nonsignificant or significant at $P \leq 0.05,0.01$, or 0.001 , respectively. Mean separation within a year among main effect means by Duncan's multiple range test, $P=0.05$, and among interaction means by $t$ test.

increase flowering of 'Gala' TC trees compared to CON trees in 1992, similar to results described by Miller (1988). The triazole PGR treatments had minimal influence, except for UNI-S, which markedly increased flowering of 'Gala' TC trees in 1990 (Table 4, Fig. 3a) and 1991 but reduced flowering in 1992. Uniconazole dosages and application methods are critical for maintaining normal flowering of a precocious cultivar like 'Gala' (Steffens and Zimmerman, 1992). However, differences in flowering of these TC trees were not necessarily reflected in the yield or fruit set. Yield of the 'Gala' triazole-treated trees never exceeded that of CON trees except for UNI-S in 1990 (Table 5, Fig. 3c).

We noted earlier (Zimmerman and Steffens, 1989) that the full potential for flowering of 'Delicious' trees was usually one season later than for 'Gala'. Because triazole gibberellin-biosynthesis inhibitors reportedly increase flowering in apple and other plants (Davis et al., 1988), we thought that the TC 'Delicious' trees might flower as soon after planting as TC 'Gala' trees in response to the applied triazole treatments. The UNI-T and UNI-S treatments stimulated flowering of 'Delicious' trees above CON in 1988 and 1989, respectively, but the results for 1990-1992 show that the earlier increases were not sustained. The flowering patterns for 'Delicious' trees treated with the triazole PGRs also show that the treatments applied did not reduce year-to-year flowering variation; rather, the triazole treatments may have increased variability of flowering (for example, see Fig. 3a). The D+E-S treatment was the only one that tended to stimulate flowering of 'Delicious' TC trees, especially the last 2 years of the experiment.

Triazole PGR treatments had little effect on increasing yield per tree for either cultivar. Cumulative fruit yields for the other triazole treatments, except for UNI-S on 'Gala' and UNI-S and PAC-T on 'Delicious', were significantly lower than CON (Table 2). TCSA of TC trees was not altered by the D+E-S treatment (Table 2), but flowering tended to be higher than for CON in several seasons (Table 4; see also Miller, 1988). Thus, a higher cumulative fruit yield per tree for 'Delicious' resulted.

Data on cumulative yield per hectare (Table 2) show that the larger number of trees of the high density planting did not fully compensate for the reduced yield per tree of the closely spaced trees. Compared to the high-density planting, the medium density planting had $36 \%$ fewer trees and the low-density planting had $50 \%$ fewer trees per hectare. However, cumulative yields per hectare of the medium and low density trees were only $7 \%$ and $20 \%$ lower, respectively, when compared to the yield of trees growing at the high density. The cumulative yields per hectare from triazole-treated trees were depressed, compared to CON trees, ca. $23 \%$ when they were grown at the high density, $15 \%$ at the medium, and $29 \%$ at the low density, indicating that the trees responded to triazole treatment similarly at all three planting densities (Fig. 4a).

Yield efficiency of 'Gala' trees was increased compared to CON by three of the five triazole treatments (UNI-S, UNI-T and UNI-P), only because these treatments reduced TCSA an average of $64 \%$ while they reduced per tree yields an average of only $19 \%$ (Table 2). Only one triazole treatment (UNI-S) increased yield efficiency of 'Delicious' trees. The UN-T and UNI-P treatments applied to 'Delicious' trees reduced both TCSA and yield $\approx 30 \%$, so that yield 

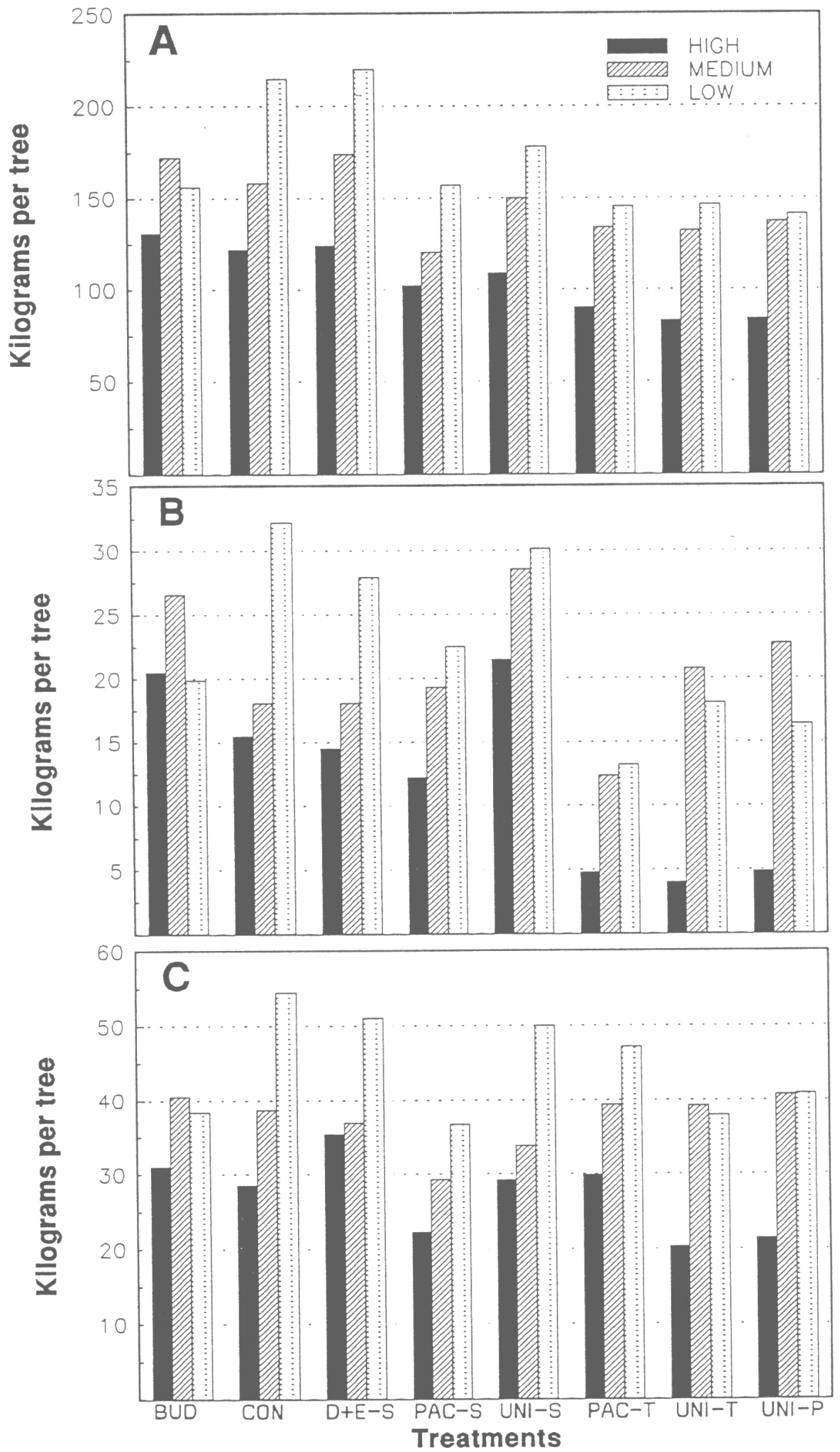

Fig. 4. Significant Interaction between planting density and growth regulator treatments for (A) cumulative yield per tree (see Table 2) and yield per tree in (B) 1989 and (C) 1991 (see Table 5).

efficiency for these two treatments was the same as for CON trees.

Bienniality indices based on fruit yields show the extent of yearto-year variations in yield-the larger the index value, the greater the tendency for year-to-year variation. Based on these indices (Table 2) 'Gala' yields in this experiment were slightly more uniform than those of 'Delicious', but there were no differences in 
bienniality between BUD and CON trees for either cultivar. Bienniality indices for 'Gala' TC trees were not influenced by any of the three uniconazole treatments or by the D+E-S treatment, but the indices were raised by both of the paclobutrazol treatments. In contrast, UNI-P was the only treatment that raised the index value for 'Delicious' TC trees, but the indices were lowered by both UNI-S and D+E-S treatments when compared to CON trees and to the other triazole-treated trees.

Burrknots. The extent of burrknots on the TC 'Gala' trees in this experiment is of concern. Tissue cultures established in 1980 were used to micropropagate these trees in late 1983. Earlier, these same 1980 cultures were used to produce trees planted in 1981; these trees did not show burrknots until about 1987. Also. the 1981 trees were not as severely affected as the trees in this experiment. Trees from the same 1980 cultures. rooted in 1986 and planted in a nursery in 1987, developed burrknots in 1987. Thus. it seems advisable to establish fresh in vitro cultures of 'Gala' annually if they are to be micropropagated for long-term field use. Such a procedure would probably apply also to other cultivars and rootstocks with a propensity for forming burrknots.

\section{Conclusions}

TC trees of 'Gala' and Triple Red 'Delicious' apple grew more vigorously than control trees budded on M.7a rootstocks. Although the 'Gala' trees were larger than those of 'Delicious' in the first few years. the 'Delicious' trees were larger after 9 years of growth. The earlier flowering and fruiting of 'Gala' with resultant heavier yields probably helped control the vigor of the TC trees. The increase in tree number as planting density increased did not increase yield per hectare proportionately. Treating the trees annually with a daminozide plus ethephon spray increased flowering in 'Delicious' more than in 'Gala', but did not control vegetative growth. Uniconazole was more effective than paclobutrazol in controlling tree size and both triazoles were more effective as planting density increased. However, the uniconazole treatments UNI-T and UNI-P at the highest planting density reduced vigor of some of the trees to the extent that their long-term survival appeared at risk. A more reasonable overall pattern of tree size control was provided by the paclobutrazol treatments PAC-S and PAC-T, although trees receiving these treatments still had a significantly larger TCSA than trees budded on M.7a. None of the triazole treatments increased fruit yield and several decreased cumulative fruit yield below that of $\mathrm{CON}$ trees. Thus, the highest yields of TC trees were obtained with the control (CON) and daminozide plus ethephon (D+E-S) treatments.

In summary, the plant growth regulators and methods of application evaluated in this study did not substitute for size-controlling rootstocks. Future research on PGRs for this purpose will depend upon availability of suitable candidate chemicals. Tissue-cultured trees may have use in commercial orchards. but are unlikely to substitute for trees on dwarfing or semi-dwarfing rootstocks. However, if commercially acceptable genetic dwarf trees can be developed (Looney and Lane. 1984), then tissue culture propagation should be feasible (Lane et al., 1982; Jones et al., 1985).

\section{Literature Cited}

Davis, T.D. and E.A. Curry. 1991 Chemical regulators of vegetative growth. Critical Rev. Plant Sci. 10:151-188.

Davis, T.D., G.L. Steffens, and N. Sankhla. 1988. Triazole plant growth regulators. Hort. Rev. 10:63-105.

Elfving, D.C. and R.A. Cline. 1990. Growth and productivity of vigorous 'Northern Spy'/MM.106 apple trees in response to annually applied growth control techniques. J. Amer. Soc. Hort. Sci. 115:212-218.

Funt, R.C., D.C. Ferree, and M.A. Ellis 1987. Influence of tree loss on rate of return of different apple production sytems. Acta Hort. 203:101106.

Hoblyn, T.N., N.H. Grubb. A.C. Painter. and B.L. Wates. 1936. Studies in biennial bearing. I. J. Pomol. Hort. SCI. 14:39-76.

Jones, A.L. and H.S. Aldwinckle (eds.). 1990. Compendium of apple and pear diseases. APS Press. St. Paul. Minn.

Jones, O.P.. R.H. Zimmerman. I.M. Fordham. and M.E. Hopfood. 1985. Propagation in vitro of some chart apple trees. J. Hort. Sci. 60:141145.

Lane, W.D.. N.E. Looney, and F. Mage. 1982. A selective tissue culture medium for growth of compact (dwarf) mutants of apple. Theoretical Applied Genet. 61:219-223.

Larsen. F.E. and S.S. Higgins. 1993. Growth and fruit production of young micropropagated apple (Malus domestica Borkh.) trees. Scientia Hort. 53:205-211.

Looney. N.E. and W.D. Lane. 1984. Spur-type growth mutants of McIntosh apple: a review of their genetics, physiology and field performance. Acta Hort. 146:31-44.

Miller, S.S. 1988. Plant bioregulation in apple and pear culture. Hort. Rev. 10:309-401

Quamme, H.A. and Brownlee. R.T. 1993. Early performance of micropropagated trees of several Malus and Prunus cultivars on their own roots. Can. J. Plant Sci. 73:847-855.

Rosati, P. and D. Gaggioli. 1987. Field performance of micropropagated peach rootstocks and scion cultivars of sour cherry and apple. Acta Hort. 212:379-390.

Rosati, P. and D. Gaggioli. 1989 Orchard response of micropropagated sour cherry and apple cultivars. Scientia Hort. 39:201-209.

SAS Institute. 1987. SAS/STAT guide for personal computers. version 6. SAS Institute. Gary. N.C.

Steffens, G.L. and R.H. Zimmerman. 1989. Management of self-rooted tissue-cultures apple trees: II. Growth regulator effects. Acta Hort. 239:121-123.

Steffens, G.L. and R.H. Zimmerman. 1990. Management systems for tissue culture propagated apple trees. Acta Hort. 285:119-126.

Steffens, G.L. and R.H. Zimmerman. 1992. Influences of uniconazole on growth. fruiting and photosynthetic activity of tissue culture-propagated own-rooted apple trees. Scientia Hort. 57:201-214.

Webster. A.D.. V.H. Ochl. J.E. Jackson, and O.P. Jones 1985. The orchard establishment, growth and precocity of four micropropagated apple scion cultivars. J. Hort Sci. 60:169-180.

Zimmerman. R.H. and I. Fordham. 1985. Simplified method for rooting apple cultivars in vitro. J. Amer. Soc. Hort. Sci. 110:34-38: 110:461462 (Corrigendum).

Zimmerman. R.H. and S.S. Miller. 1991. Orchard growth and fruiting of micropropagated apple trees. J. Amer. Soc. Hort. Sci. 116:780-785.

Zimmerman. R.H. and G.L. Steffens. 1989. Management of self-rooted tissue-cultured apple trees. I. Orchard establishment and early growth. Acta. Hort. 239:117-120. 